\title{
THERMAL PERFORMANCE AND FLAME TEMPERATURES ON LPG RADIAL BURNERS IN DOMESTIC COOKERS
}

\author{
R. L. da Silva ${ }^{a}$, \\ L. S. Azevedo ${ }^{a}$, \\ B. V. Sant' Anna ${ }^{a}$, \\ J. R. Patelli Jr. a, \\ and M. M. Vieira ${ }^{b}$ \\ ${ }^{\mathrm{a}}$ Universidade Federal da Grande Dourados \\ Faculdade de Engenharia - FAEN / UFGD \\ Rodovia MS-270, km 12, CEP 79.804-970 \\ Dourados, Mato Grosso do Sul, Brasil \\ rlealsilva@hotmail.com \\ leandroazevedosd@gmail.com \\ bruno.viscardi@hotmail.com \\ jrpjunio@uol.com.br \\ ${ }^{\mathrm{b}}$ Universidade Federal de Rondonópolis \\ Engenharia Mecânica / ICAT - UFR \\ Rodovia MT-270, km 06, CEP 78.735-901 \\ Rondonópolis, Mato Grosso, Brasil \\ mmendes@ufmt.br \\ Received: April 22, 2019 \\ Revised: May 25, 2019 \\ Accepted: August 21, 2019
}

\begin{abstract}
The objective is to investigate radial burners through experimental tests, looking for its thermal performance behavior. Gas burners in domestic cookers operate on LPG, typically with two different geometries and five thermal power conditions. Usually, those thermal equipment lacks information on its whole operating conditions range for higher energy conversion efficiency and lower fuel consumption; it is not pointed out by the manufacturer or by energy efficiency labeling, what could result in a recommendation for widely effective performance. Appropriate instrumentation was used to carry out the measurements and methodology used as a guideline regulations from INMETRO/CONPET, ABNT Brazilian Technical Standards Normative, and ANP - National Agency of Petroleum, Natural Gas and Biofuels. Experimental measurements and uncertainties are for the following parameters: fuel mass consumption $\left(\mathrm{kg} . \mathrm{s}^{-}\right.$ $\left.{ }^{1}\right)$, test time elapsed $(\mathrm{s})$, temperature $\left({ }^{\circ} \mathrm{C}\right)$, water mass $(\mathrm{kg})$ and flame temperature by K-type thermocouples (quantitative) and a thermal camera (qualitative). Main conclusions are: a) Operating domestic cookers with handle position selector on middle position (TP3) provides almost the same temperature rise as maximum fuel consumption (TP5), i.e., $\Delta \mathrm{T}$ in the water container; b) Heat is better transferred $\left(\mathrm{Q}_{\text {gas }} \rightarrow \mathrm{Q}_{\text {water }}\right)$ with the handle position selector fully opened (TP5@B1) and just before fully opening (TP4@B2); c) A non-linear behavior occurs for $\eta_{\text {Thermal }}$, when moving forward the handle position selector; maximum efficiency occurs at fully open (TP5@B2) and middle opening (TP3@B1); d) Higher values for $\mathrm{TP}_{\text {experimental }}$ occurs for $\mathrm{B} 2$, in comparison to $\mathrm{B} 1$, in whole operational condition ranges; differences are mainly due to geometric parameters $\left(\mathrm{AR}_{\mathrm{B} 2} / \mathrm{AR}_{\mathrm{B} 1} \sim 0.82\right)$. In general, $\mathrm{B} 2$ has a better geometric design; e) Uncertainty analysis indicate values lower than $\pm 3 \%$, proving to be a suitable methodology for the experimental results in this work; f) Flame temperatures are entirely consistent with both, $\eta_{\text {Thermal }}$ and heat energy delivered, reaching higher temperature values at TP4 for both burners;
\end{abstract} $751.5^{\circ} \mathrm{C}(\mathrm{B} 1)$ and $830.7^{\circ} \mathrm{C}(\mathrm{B} 2)$.

Keywords: energy efficiency; energy labels; combustion; premixed flames

\section{NOMENCLATURE}

AR aspect ratio

B burner

$\mathrm{C}_{\mathrm{p}} \quad$ specific heat at constant pressure, $\mathrm{kJ} \cdot \mathrm{kg}^{-1} \cdot \mathrm{K}^{-1}$

De external diameter, $\mathrm{mm}$

$\mathrm{Di} \quad$ internal diameter, $\mathrm{mm}$

$\mathrm{h}_{\mathrm{w}} \quad$ water specific heat, $4.178 \mathrm{~kJ} \cdot \mathrm{kg}^{-1} \cdot \mathrm{K}^{-1}$

$\mathrm{H}$ height, $\mathrm{mm}$

HHV high heating value, ${\mathrm{J} . \mathrm{kg}^{-1}}^{-1}$

LHV low heating value, ${\mathrm{J} . \mathrm{kg}^{-1}}^{-1}$

LPG liquefied petroleum gases

m mass, $\mathrm{kg}$

mp mass flow, kg.s ${ }^{-1}$

NG natural gas

$\mathrm{p} \quad$ pressure, $\mathrm{kPa}$

PRRP porous radiant recirculated burner

Q heat transferred or received, J.kg-1

Re Reynolds number

$\mathrm{RH}$ relative humidity, \%

$\mathrm{S}$ area, $\mathrm{cm}^{2}$

SB swirling central flame ring burner

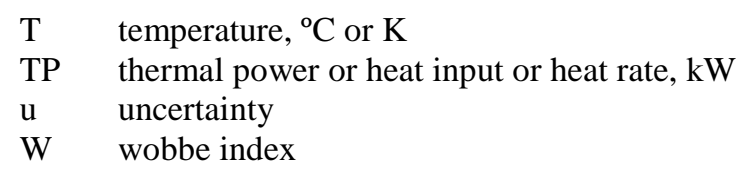

\section{Greek symbols}

$\rho \quad$ density, kg.m ${ }^{-3}$

$\Delta \quad$ differences (temperature, mass, time, etc)

$\eta \quad$ energy conversion efficiency, \%

Subscripts
adiabatic adiabatic condition
boiling boiling condition
cap cap (burner's top surface)
cyl cylinder
dry dry condition (without moisture)
f fuel
flame
g flame reference (temperature)
lab laboratory ambient conditions


Nominal nominal values

Max maximum

Min minimum

C chronometer uncertainty

$\mathrm{T}$ thermometer uncertainty

Thermal thermal energy

p constant pressure condition

w water

\section{INTRODUCTION}

Industrial and residential burners are thermal equipment that converts fuel's chemical energy (HHV, J.kg-1), into thermal energy (heat, J) typically through a combustion process. For industrial applications, equally liquid and gas fuels are usual, while that for residential use, gas fuel is preferable; it ensures better conditions for complete combustion what is safer for indoor air pollution, and lowers $\mathrm{CO}_{2}$ emissions and other greenhouse gases. Other than energy conversion efficiency, concerns on environmental impact and pollutant emissions when performing combustion of fossil fuels (nonrenewable fuels) are also of great importance.

For residential burners, there is available a significant number of commercial models for domestic use. Nevertheless, it's harder for the ordinary citizen to choose better equipment considering its energy conversion efficiency than other economic criteria. Since 2001, Brazil's energy efficiency law (Brasil, 2001) has proposed to point out precisely, to the final consumer, for any equipment in the market that consumes energy, how is its energy performance compared to others also available in the market. Regulations for safety and performance, applied for domestic burners and ovens, are available (INMETRO, 2012).

Many literature results are looking for an evaluation of gas burners for domestic use purposes, typically operating with impinging premixed flames (Turns, 2013). For example, assessment of thermal performance and $\mathrm{CO}$ emissions in a residential cooker-top burner operating at low pressure and low Reynolds numbers ( $\mathrm{Li}$ et al., 2006); were authors analyze experimental data for cooker top-burner (3mm inner diameter) and evaluate design parameters as: Reynolds number, equivalence ratio, nozzle-toplate distance, and jet-to-jet spacing. Their findings point out that thermal efficiency and $\mathrm{CO}$ emissions are strongly affected by the design parameters reported. In domestic burners, LPG (Liquefied Petroleum Gases) is the most common fuel, once that the combustion products are relatively clean (Hou, Lee, and Lin, 2007). Even then, there is a permanent search for higher energy efficiency and lower emissions to reduce residential fuel consumption.

Thermal efficiency in domestic gas burners is one of the main requirements and an increasing concern for society. Thus, there are increasing studies in conversion efficiency and emissions for LPG gas burners; even small improvements in overall performance or lowering emissions will have significant benefits on costs and environment.

LPG combustion typically results in lower emissions levels, for example, $\mathrm{CO}_{2}, \mathrm{SO}_{\mathrm{x}}$, and $\mathrm{NO}_{\mathrm{x}}$, when compared to other fossil fuels as diesel oil. Then, even being a fossil fuel (classified as a nonrenewable energy source), it is an attractive option for residential applications among others as natural gas (HHV $\sim 40,000 \mathrm{~kJ}^{-1} \mathrm{~kg}^{-1}$ ) and biogas (HHV $\sim 50,000 \mathrm{~kJ}^{\mathrm{kg}}{ }^{-1}$ ). Other LPG relevant characteristics are small volume storage (compressed liquid phase is 250 times lower than its gaseous phase), and density upper limits $\sim 550 \mathrm{~kg} . \mathrm{m}^{-3}$. LPG main components are propane $\left(\mathrm{C}_{3} \mathrm{H}_{8}\right)$, propene $\left(\mathrm{C}_{3} \mathrm{H}_{6}\right)$, butane $\left(\mathrm{C}_{4} \mathrm{H}_{10}\right)$, and butene $\left(\mathrm{C}_{4} \mathrm{H}_{8}\right)$; Propane and butane $\mathrm{HHV}$ is $\sim 50,000$ $\mathrm{kJ} . \mathrm{kg}^{-1}$ (http://www.petrobras.com.br/minisite/assis tenciatecnica, accessed on Setember, 2014), what is $\sim 22 \%$ superior to $\mathrm{HHV}_{\text {gasoline }}\left(\sim 41,000 \mathrm{~kJ} \mathrm{~kg}^{-1}\right)$.

Results obtained for residential gas burners indicate that thermal efficiency performance was not satisfactory when using as fuel, natural gas with variable constituents (Zhang et al., 2013). Recent discussions on energy efficiency improvements on domestic gas burners (Zhen et al., 2014), look for redesigning the burner cap to obtain swirling flows; once premixed flames usually have restricted operational range, thus getting larger ones and lower CO emission. The most widely used gas burners are the conventional Bunsen type, which is partially aerated (Ko and Lin, 2003); in those types, typically primary air is naturally dragged as a consequence of the momentum quantity due to the gas jet flow, at high velocity, and the ambient air.

There exists worldwide, intensive use of gas burners coupled in cooker-top devices for daily home cooking and heating. Thus better thermal efficiency and low fuel consumption, as well as low emissions in this environment, are desirable and pursued through experimental and computational research to be developed in domestic burners operating with LPG and other gaseous fuels.

The objective in this paper is to identify, for a cooker-top gas burner, its main characteristics in the whole operational conditions range and which one provides better performance (higher efficiency and lower fuel consumption), typically not indicated by the manufacturer. Evaluation is through laboratory tests for a residential gas burner operating with commercial LPG, with two different geometries (diameter and height) and five thermal power conditions (TP1 up to TP5, heat inputs); at constant fuel mass flow in each of those conditions. Brazilian standards for energy efficiency labeling programs are the guidelines for the experiments.

\section{METHODOLOGY}

Burner Specification and Experimental Set-up 
Tests are in a residential gas burner, cooker-top type, with the following technical data (http://www.atlas.ind.br/site/pt/produtos/49/fogao-agas-tropical-plus-4-bocas, accessed on September, 2014): LPG as fuel; weight $20.90 \mathrm{~kg}$; automatic, electric ignition (127/220 V); “A” as Brazilian labelling classification for both, burner and oven, according to CONPET - National Program to Rationalize the use of Petroleum and Natural Gas Derivatives (INMETRO, 2012); $\mathrm{TP}_{\text {Nominal }}=1.67 \mathrm{~kW}$ (0.65mm injector diameter), i.e., heat input rate or firing rate. Thus, that cooker-top burner is classified as "semi-fast" (1.16 up to $2.30 \mathrm{~kW}$ ), while "fast" range is from $2.30 \mathrm{~kW}$ up to $3.50 \mathrm{~kW}$; and, for $\mathrm{TP}_{\text {Nominal }} \leq 2.25 \mathrm{~kW}$, tolerance in all four burners is $\pm 8 \%$ (ABNT, 2003). Figure 1 shows the experimental apparatus for performance tests.

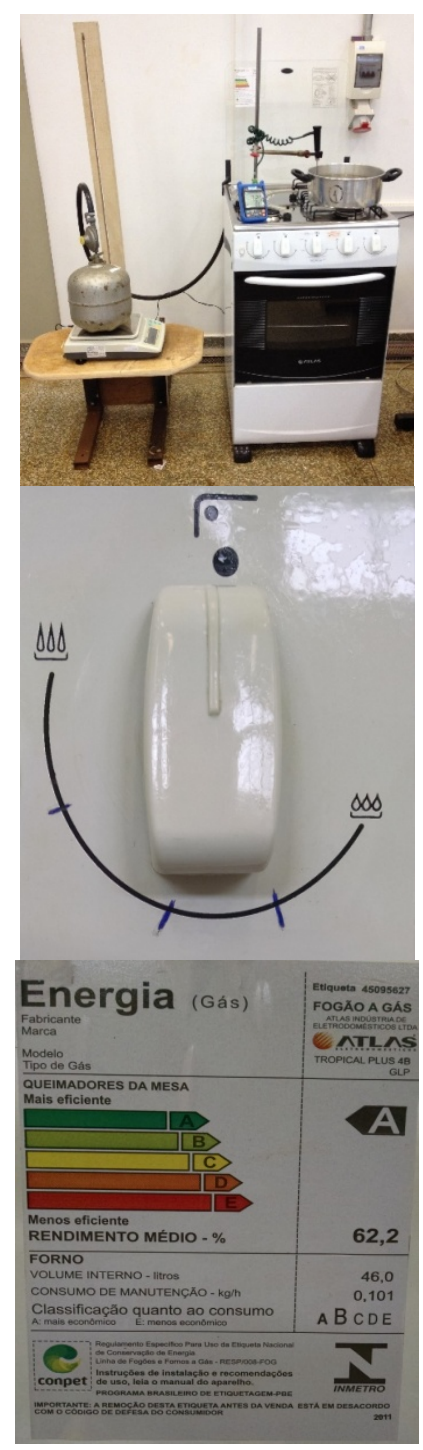

Figure 1. Experimental apparatus, TP levels (handle position selector), and energy efficiency labeling.

Radial cooker-top burners for tests have, as manufactured: two different geometry design, identified as B1 (Burner “1”) and B2 (burner “2”); see Fig. 2 and Tab. 1. The geometry configuration of the burner head (or "Cap") influences the flame flow pattern, in here both are radial flow types. Five thermal power conditions are evaluated (TP, kW), namely, from minimum to maximum $\mathrm{mpg}_{\mathrm{g}}\left(\mathrm{kg} . \mathrm{s}^{-1}\right)$ : TP1, TP2, TP3, TP4, and TP5.

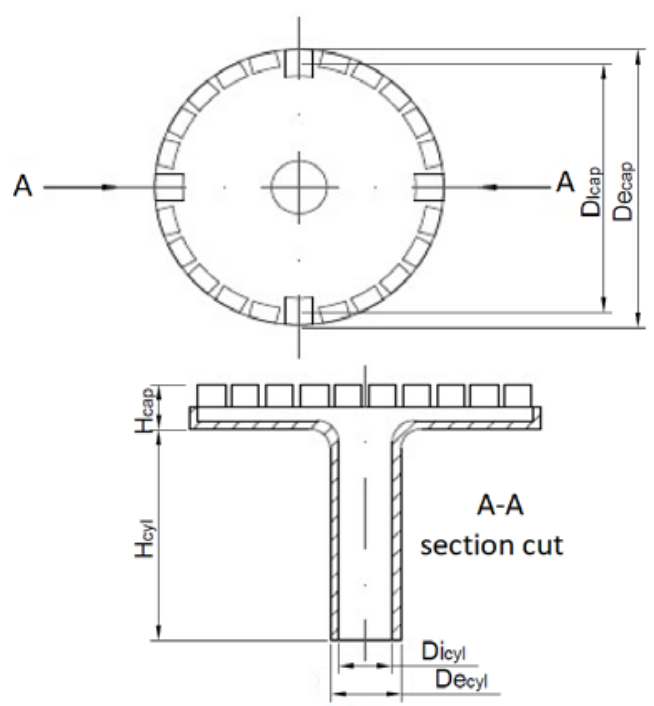

Figure 2. Burner, top and lateral views.

Table 1. Burner's geometry (mm).

\begin{tabular}{|l|c|c|}
\hline & $\begin{array}{c}\mathrm{B} 1 \\
(1-\alpha)\end{array}$ & $\begin{array}{c}\mathrm{B} 2 \\
(1-\beta)\end{array}$ \\
\hline Cap external diameter, $\mathrm{De}_{\mathrm{cap}}$ & 64.570 & 77.340 \\
\hline Cap internal diameter, $\mathrm{Di}_{\mathrm{cap}}$ & 60.860 & 73.520 \\
\hline Cap height, $\mathrm{H}_{\mathrm{cap}}$ & 10.230 & 10.440 \\
\hline Cylinder external diameter, $\mathrm{De}_{\mathrm{cyl}}$ & 16.150 & 15.150 \\
\hline Cylinder internal diameter, $\mathrm{Di}_{\mathrm{cyl}}$ & 12.350 & 11.870 \\
\hline Cylinder height, $\mathrm{H}_{\mathrm{cyl}}$ & 50.200 & 49.430 \\
\hline Aspect Ratio $\left(\mathrm{H}_{\mathrm{cyl}} / \mathrm{De}_{\mathrm{cap}}\right)$ & 0.78 & 0.64 \\
\hline
\end{tabular}

\section{Instrumentation for Measurements}

Table 2 indicates instrumentation and uncertainties in experimental measurements. Uncertainty analysis was performed for each one of the parameters obtained in tests, whenever feasible (Balbinot and Brusamarello, 2010).

Table 2. Instrumentation and devices for tests.

\begin{tabular}{|l|r|r|r|}
\hline Instrumentation & Quantity & Resolution & Accuracy \\
\hline Scale & Mass & $0.1 \mathrm{~g}$ & $\pm 0.1 \mathrm{~g}$ \\
\hline Barometer & Pressure & $10 \mathrm{~Pa}$ & $\pm 150 \mathrm{~Pa}$ \\
\hline Manometer & Pressure & $0.5 \mathrm{kgf.cm}^{-2}$ & $\pm 0.25 \mathrm{kgf.cm}^{-2}$ \\
\hline Chronometer & Time & $1 / 100^{\prime \prime}$ & $\pm 1 / 200^{\prime \prime}$ \\
\hline Thermocouple & Temperature & $0.1^{\circ} \mathrm{C}$ & $\pm 0.1^{\circ} \mathrm{C}$ \\
\hline Water container & \multicolumn{3}{|c|}{ Aluminun; $1.5 \mathrm{~mm}$ thickness; } \\
\hline Thermal camera & Temperature diameter: $207-211 \mathrm{~mm}$ \\
\hline
\end{tabular}


(FLIR, E50)

Thermal camera and thermocouple (K-type)

Thermal camera (E50 model) operates in temperature ranges from $-20^{\circ} \mathrm{C}$ up to $650^{\circ} \mathrm{C}$; Infrared resolution $240 \times 180$ pixels; Frame rate $60 \mathrm{~Hz}$; weight $0.825 \mathrm{~kg}$ (http://www.flir.com/thermography/ americas $/ \mathrm{br} / \mathrm{view} /$ ?id=56911\&collectionid=939\&col= 50850, accessed on September, 2014). Thermal images obtained herein are only of a qualitative; thus, emissivity does not have a significant influence. Nevertheless, calibration for emissivity (based on the contact thermometer method) and compensation of apparent reflected temperature were performed according to standards normative (ABNT, 2014 and 2016).

A K-type thermocouple was used to register flame temperatures; maximum value recorded during 3 minutes with a thermocouple inside the flame. Flames in the burner can reach temperatures over $900^{\circ} \mathrm{C}$, but $650^{\circ} \mathrm{C}$ is the maximum values registered by the thermal camera available in the labs.

Thermal image measurement procedure was adapted, considering what follows: take the images from the same distance (fixed position) from the flames in which temperature values registered were lower than its saturation value $\left(650^{\circ} \mathrm{C}\right)$. Even if temperature values are not quantitatively correct on a thermal camera, the equipment could provide a qualitative flame field for comparison at different TP.

\section{Laboratory and Test Standard Conditions}

Tests were carried out under laboratory conditions for data acquisition as indicated by NBR 13.723-1 and NBR 13.723-2 (ABNT, 2003; 1999), as $\mathrm{T}_{\text {lab }}=(25 \pm 5)^{\circ} \mathrm{C}$. Eventually, a single run could be slightly different but does not interfere in the overall behavior of the results, discussions, and conclusions presented herein. Results for experimental tests were obtained at the following ranges: $27.5^{\circ} \mathrm{C} \leq \mathrm{T}_{\text {lab }} \leq$ $28.3^{\circ} \mathrm{C}$, and for recording only, $49 \% \leq \mathrm{RH}_{\mathrm{lab}} \leq 52 \%$ and $96.29 \mathrm{kPa} \leq \mathrm{p}_{\text {lab }} \leq 96.35 \mathrm{kPa}$.

The LPG pressure inside the pressure vessel ( $\mathrm{P}$ 2) must be higher than $1.96 \mathrm{kPa}$ (ABNT, 1993); after tests completion, it was from $686.5 \mathrm{kPa}\left(7 \mathrm{kgf} . \mathrm{cm}^{-2}\right)$ down to $539.4 \mathrm{kPa}$ (5.5 kgf. $\mathrm{cm}^{-2}$ ), measured with a manometer (Tab. 2). Regarding the fuel supply line, the pressure is kept constant during all tests; it allows to reflect the regular operation in the household, thus increases in TP $(\mathrm{kW})$ automatically increases $\mathrm{mp}_{\text {Nominal }}\left(\mathrm{kg} \cdot \mathrm{s}^{-1}\right.$ ). The pressure regulator (governor, Aliança, model 506/01) is designed to provide a constant value $(2.8 \mathrm{kPa}$ as nominal pressure for residential use, i.e., low pressures) at $\mathrm{mp}_{\mathrm{Max}} \leq 2 \mathrm{~kg} \cdot \mathrm{h}^{-}$ ${ }^{1}$ (ABNT, 2005).

\section{Reference Data and Wobbe Index} follows:

$$
\mathrm{W}_{\text {index }}=\mathrm{HHV} \cdot\left[\rho_{\text {LPG-Dry }} / \rho_{\text {Air-Dry }}\right]^{-1}
$$

Fuel properties reference values for Brazilian commercial LPG, typically propane/propene and butane/butane, are (Turns, 2013; http://www. petrobras.com.br/minisite/assistenciatecnica, acessed on Setember, 2014): HHV = 49,330 kJ.kg-1 $\mathrm{LHV}=$

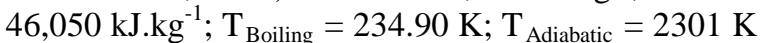
$\left(2028{ }^{\circ} \mathrm{C}\right)$ is the adiabatic flame temperature $\left({ }^{\circ} \mathrm{C}\right.$ or $\mathrm{K}) ; \rho=547 \mathrm{~kg} \cdot \mathrm{m}^{-3}$. Those data are required to Eq. (1).

\section{Experimental procedures for Brazilian Regulation}

The following process was applied in all tests, with measurements at the test beginning and ending: (i) Ambient conditions and pressure check (manometer) inside the P-2 vessel; (ii) Fuel mass consumed in the test (mass flow), thus no corrections are required as it would be the case when volumetric flow is measured (Cassol et al., 2007).

Nominal TP and the $\mathrm{S}_{\text {Minimum }}$ for performance tests are as defined by standards (ABNT, 2003):

$$
\begin{aligned}
& \left(T P_{\text {Nominal }}\right)=\left(1000.8 H H V . m p_{\text {Nominal }}\right) \\
& \left(S_{\text {Minimum }}\right)=\left(191 . T P_{\text {Nominal }}\right)
\end{aligned}
$$

Where: HHV = High Heating Value $\left(\mathrm{kJ} \mathrm{kg}^{-1}\right)$; $\mathrm{mp}_{\text {Nominal }}=$ Nominal fuel mass flow during tests $\left(\mathrm{kg} . \mathrm{s}^{-1}\right) ; \mathrm{S}_{\text {Minimum }}=$ Recipient area $\left(\mathrm{cm}^{2}\right) ; \mathrm{TP}_{\text {Nominal }}=$ Burner's nominal heat input or firing rate $(\mathrm{kW})$.

\section{Experiment 1: $\Delta T=f(\Delta t)$, water heating capacity}

To perform direct measurements by using a thermocouple and a chronometer, for $\mathrm{T}_{\mathrm{w}}\left({ }^{\circ} \mathrm{C}\right)$ and $\mathrm{t}$ (s) until test completion after 600s (10 minutes). The following steps were applied: 1a) Mass measurements of water ( $\sim 2 \mathrm{~kg}$ and $20 \pm 1^{\circ} \mathrm{C}$ ) and container (one standard water pan), then fill in; 2a) Burner's ignition, positioning the container at the center burner's flame; 3a) Thermocouple standing at the container's center; 4a) Burner's shut down after reaching 600s (10 minutes), recording water temperature each 30s; 5a) Repeat steps for each TP setting.

$\mathrm{T}_{\mathrm{w}}$ at the test beginning was the same for all conditions, to have the same reference; $(20 \pm 1)^{\circ} \mathrm{C}$ as indicated by ABNT (2003).

Measured values are: $\mathrm{m}_{\mathrm{w}}(\mathrm{kg})$ is the water mass inside the standard recipient; $h_{w}=4.178\left(\mathrm{~kJ} \mathrm{~kg}^{-1} \cdot \mathrm{K}^{-1}\right)$ is the water specific heat; $\Delta \mathrm{T}(\mathrm{K})$ is the water temperature rise; $\Delta \mathrm{t}(\mathrm{s})$ is the time elapsed in the test.

\section{Experiment 2: $m_{f}$ and $T P$}

The following steps were applied: 1b) Burner's ignition and shut down after 300s (5 minutes); 2b) 
Repeat steps for each TP set.

Measured values are: $\Delta \mathrm{m}(\mathrm{kg})$ and $\Delta \mathrm{t}(\mathrm{s})$; while $\mathrm{mp}_{\text {gas }}\left(\mathrm{kg} . \mathrm{s}^{-1}\right)$ and $\mathrm{TP}_{\text {experimental }}(\mathrm{kW})$ and its respective uncertainties are determined as follows, as well as $\mathrm{T}_{\mathrm{g}}$ $(\mathrm{K})$ :

$$
\begin{gathered}
m p_{\text {gas }}=\Delta m / \Delta t \\
u_{\text {mp-gas }}=\left(\left(u_{\Delta m} \cdot \Delta t^{-1}\right)^{2}+\left(u_{\Delta t} \cdot-\Delta m \cdot \Delta t^{-2}\right)^{2}\right)^{1 / 2} \\
T P_{\text {Experimental }}=m p_{\text {gas }} \cdot H H V \\
u_{\text {TP-gas }}=\left(\left(u_{\text {mp-gas }} \cdot H H V\right)^{2}+\left(u_{H H V} \cdot m\right)^{2}\right)^{1 / 2}
\end{gathered}
$$

assuming that $\mathrm{u}_{\mathrm{HHV}}=0(\mathrm{HHV}=\mathrm{cte})$.

$$
T_{\text {gas }}=T_{\text {air }}+\left(m_{f} \cdot L H V\right) \cdot\left(m p_{\text {gas }} \cdot c p_{\text {gas }}\right)^{-1}
$$

$\mathrm{T}_{\text {gas }}$, given by Eq. (6), is a theoretical value when assuming that all the heat resulted from the combustion process is converted into enthalpy of the combustion products; thus there is no heat transfer to the environment or heat loss by fuel dissociation (Garcia, 2002).

\section{Experiment 3: $\eta_{\text {Thermal }}$ (energy conversion efficiency)}

The following steps were applied: 1c) Mass measurements for water ( 2 $\mathrm{kg}$ and $\left.20 \pm 1^{\circ} \mathrm{C}\right)$ and water containers (two standard water pans), then fill one of them; 2c) Burner's ignition and water preheating during the 600s (10 minutes). Note: Container positioning at the center burner's flame; 3c) Transferring pre-heated water into another container; 4c) Thermocouple standing at the container's center; $5 c$ ) Burner's shut down when $\mathrm{T}_{\mathrm{w}}$ $=(90 \pm 1)^{\circ} \mathrm{C}$, recording maximum $\mathrm{T}_{\mathrm{w}}$ after shutdown; $6 c)$ Repeat steps for each TP setting.

Measured values are: $\mathrm{m}_{\mathrm{w}}(\mathrm{kg}), \Delta \mathrm{T}(\mathrm{K})$ and $\Delta \mathrm{t}$

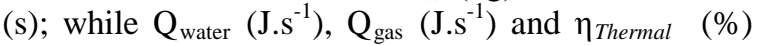
and its respective uncertainties given are determined as follows, as well as Reynolds number:

$$
\begin{gathered}
Q_{\text {gas }}=\Delta m \cdot H H V \\
u_{Q-g a s}=\left(\left(u_{\Delta m} \cdot H H V\right)^{2}+\left(u_{H H V} \cdot \Delta m\right)^{2}\right)^{1 / 2} \\
\text { assuming that } \mathrm{u}_{\mathrm{HHV}}=0(\mathrm{HHV}=\mathrm{cte}) . \\
Q_{w}=m_{w} \cdot h_{w} \cdot \Delta t \\
u_{Q-w}=\left(\left(u_{m-w} \cdot h_{w} \cdot \Delta T\right)^{2}+\left(u_{h-w} \cdot m_{w} \cdot \Delta T\right)^{2}\right. \\
\left.+\left(u_{\Delta T} \cdot m_{w} \cdot h_{w}\right)^{2}\right)^{1 / 2}
\end{gathered}
$$

assuming that $\mathrm{u}_{\mathrm{h} \text {-water }}=0$ ( $\left.\mathrm{h}=\mathrm{cte}\right)$.

$$
\begin{gathered}
\eta_{\text {Thermal }}=\left(Q_{w} / Q_{g}\right) \cdot 100 \\
u_{\eta}=\left(\left(u_{Q-w} \cdot Q_{\text {gas }}^{-1} \cdot 100\right)^{2}+\left(u_{Q-\text { gas }} \cdot-Q_{w} \cdot Q_{\text {gas }}^{-2}\right)^{2}\right)^{1 / 2}
\end{gathered}
$$

$$
R_{e}=\rho_{L P G} \cdot v \cdot D i_{c y l} / \mu_{L P G}
$$

Burner's thermal efficiency, Eq. (9a), is defined as a percentage of the thermal energy input transferred to the water in the container (Hou et al., 2007; Makmool et al., 2007).

Internal flow, considering burner's geometric data (see Fig. 2 and Tab. 1), provides Reynolds number, Eq. (10). Reynolds number considers fuel gas properties, thus flow conditions before air entrainment that occurs in premixed flames burners. Consider fuel+air for $\mathrm{Re}$ calculation would require measurements on the burner's exit, not available in this work (airflow was not measured).

\section{RESULTS AND DISCUSSION}

LPG (mean properties) provides $\mathrm{W}_{\text {index }}=2237$ $\mathrm{kJ} \mathrm{kg}^{-1}$ or $1.22 \mathrm{E}+06 \mathrm{~kJ} . \mathrm{m}^{-3}$; and would reach the highest value for LPG with $100 \%$ of $\mathrm{C}_{3} \mathrm{H}_{8}$ (2389 $\left.\mathrm{kJ} \mathrm{kg}^{-1}\right)$ or with $100 \%$ of $\mathrm{C}_{4} \mathrm{H}_{10}\left(1.26 \mathrm{E}+06 \mathrm{~kJ}^{-3}\right)$. TP achieves higher values as high is $\mathrm{W}_{\text {index }}$ (Zhang et al., 2013); and, on the other hand, it also implies in a CO emission raise, which is also limited to the specified values for domestic cooking appliances according to each country standard normative.

As $S_{\text {Minimum }}$ is $\sim 320 \mathrm{~cm}^{2}$, tests used two loading vessels (207-211 mm outer diameter; $\sim 336 \mathrm{~cm}^{2}$ and $\sim 350 \mathrm{~cm}^{2}$ ) for containing water as the heat-absorption system. For literature results comparison, it considers an outer diameter of $250 \mathrm{~mm}$ (Li et al., 2006).

\section{Heating capacity tests}

Results for water heating from fuel gas burning are in Tab. 3, with its corresponding energy conversion efficiency $\left(\eta_{\text {Thermal }}\right)$. The lowest and highest fuel consumption occurs, respectively: for B1 at TP3@31.8g and TP1@99.0g; for B2 at TP5@24.7g and TP1@48.6g, what resulted, respectively, in their highest and lowest efficiency in Fig. 3(b). As a general behavior, for a standard water mass and temperature increase $(\Delta \mathrm{T})$, the lower LPG mass consumed for the same required time $(\Delta \mathrm{t})$, the higher is $\eta_{\text {Thermal }}$ (\%). As for energy conversion efficiency, results indicate that its uncertainties $\left(\mathrm{u}_{\eta}\right)$ are more dependent on $\mathrm{u}_{\text {Qgas }}$ than $\mathrm{u}_{\mathrm{Qw}}$. Thus, maximum relative standard uncertainties are $0.4 \%$ for $\mathrm{u}_{\eta}$ and $0.2 \%$ of all $\mathrm{u}_{\text {Qgas }}$ values.

Figure 3 indicates the heating capacity behavior for $\mathrm{B} 1$ and $\mathrm{B} 2$, which in general approaches to a linear increase. Uncertainties are the same as the ones 
of the measuring instruments (thermometer, $\mathrm{u}_{\mathrm{T}}= \pm 0.1^{\circ} \mathrm{C}$; chronometer, $\mathrm{u}_{\mathrm{C}}= \pm 0.005 \mathrm{~s}$ ) since data acquisition is obtained directly. For B1, highest and lowest $\Delta \mathrm{T}$ slope is achieved by TP5 and TP2 respectively; with TP1 very close to TP2. A similar situation occurs for B2, once TP4 deliver the highest $\Delta \mathrm{T}$ slope followed close by TP5 and TP3; and lowest $\Delta \mathrm{T}$ appears for TP1, clearly different from TP2. Thus, besides $\eta_{\text {TP2 }}>\eta_{\text {TP1 }}$ (see Tab. 3), TP2 is the worst option for B1 (AR = 0.78), once the burner's ultimate purpose is to provide energy as a heating source (i.e., water in tests). The same conclusion applies to TP1 in B2 (AR = 0.64), being the worst operational condition. That is, reaching the same order of magnitude for temperature, TP3 (for B2) consumes less fuel $\left(\Delta \mathrm{m}_{\mathrm{g}}\right)$ achieving the same heating capacity level.

Table 3. Heat transfer between fuel gas and water.

\begin{tabular}{|c|c|c|c|c|c|c|c|}
\hline & & $m_{g}(g)$ & $\Delta \mathrm{m}_{\mathrm{g}}(\mathrm{g}$ & $\Delta \mathrm{T}_{\mathrm{w}}\left({ }^{\circ} \mathrm{C}\right)$ & $\mathbf{Q}_{\text {gas }}(\mathbf{k J}$ & $\mathbf{Q}_{\mathrm{w}}(\mathbf{k J}$ & $\eta(\%)$ \\
\hline \multirow[t]{2}{*}{ TP1 } & B1 & 2000.1 & 99.0 & 66.5 & $\begin{array}{l}4883.7 \\
\pm 0.1 \% \\
\end{array}$ & $\begin{array}{c}555.7 \\
\pm 0.2 \% \\
\end{array}$ & $\begin{array}{c}11.4 \\
\pm 0.1 \% \\
\end{array}$ \\
\hline & B2 & 2000.0 & 48.6 & 65.9 & $\begin{array}{l}2397.4 \\
\pm 0.2 \%\end{array}$ & $\begin{array}{c}550.7 \\
\pm 0.2 \% \\
\end{array}$ & $\begin{array}{r}23.0 \\
\pm 0.2 \% \\
\end{array}$ \\
\hline \multirow[t]{2}{*}{ TP2 } & B1 & 2000.3 & 61.5 & 67.5 & $\begin{array}{l}3033.8 \\
\pm 0.2 \% \\
\end{array}$ & $\begin{array}{c}564.1 \\
\pm 0.2 \% \\
\end{array}$ & $\begin{array}{r}18.6 \\
\pm 0.2 \% \\
\end{array}$ \\
\hline & B2 & 2000.4 & 36.3 & 67.5 & $\begin{array}{l}1790.7 \\
\pm 0.3 \%\end{array}$ & $\begin{array}{c}564.1 \\
\pm 0.2 \%\end{array}$ & $\begin{array}{r}31.5 \\
\pm 0.3 \% \\
\end{array}$ \\
\hline \multirow{2}{*}{ TP3 } & B1 & 2000.7 & 31.8 & 67.9 & $\begin{array}{l}1568.7 \\
\pm 0.3 \%\end{array}$ & $\begin{array}{c}567.6 \\
\pm 0.2 \%\end{array}$ & $\begin{array}{r}36.2 \\
\pm 0.3 \%\end{array}$ \\
\hline & B2 & 2000.1 & 37.5 & 66.6 & $\begin{array}{l}1849.9 \\
\pm 0.3 \% \\
\end{array}$ & $\begin{array}{r}556.5 \\
\pm 0.2 \% \\
\end{array}$ & $\begin{array}{r}30.1 \\
\pm 0.3 \% \\
\end{array}$ \\
\hline \multirow[t]{2}{*}{ TP4 } & B1 & 2000.3 & 62.0 & 67.1 & $\begin{array}{l}3058.5 \\
\pm 0.2 \%\end{array}$ & $\begin{array}{c}560.8 \\
\pm 0.2 \%\end{array}$ & $\begin{array}{c}18.3 \\
\pm 0.2 \%\end{array}$ \\
\hline & B2 & 2000.0 & 39.5 & 68.5 & $\begin{array}{l}1948.5 \\
\pm 0.3 \% \\
\end{array}$ & $\begin{array}{c}572.4 \\
\pm 0.2 \% \\
\end{array}$ & $\begin{array}{r}29.4 \\
\pm 0.3 \% \\
\end{array}$ \\
\hline \multirow[t]{2}{*}{ TP5 } & B1 & 2000.0 & 44.3 & 67.1 & $\begin{array}{l}2185.3 \\
\pm 0.2 \% \\
\end{array}$ & $\begin{array}{c}560.7 \\
\pm 0.2 \% \\
\end{array}$ & $\begin{array}{r}25.7 \\
\pm 0.2 \% \\
\end{array}$ \\
\hline & B2 & 2000.3 & 24.7 & 64.9 & $\begin{array}{l}1218.5 \\
\pm 0.4 \%\end{array}$ & $\begin{array}{c}542.4 \\
\pm 0.2 \%\end{array}$ & $\begin{array}{r}44.5 \\
\pm 0.4 \%\end{array}$ \\
\hline
\end{tabular}

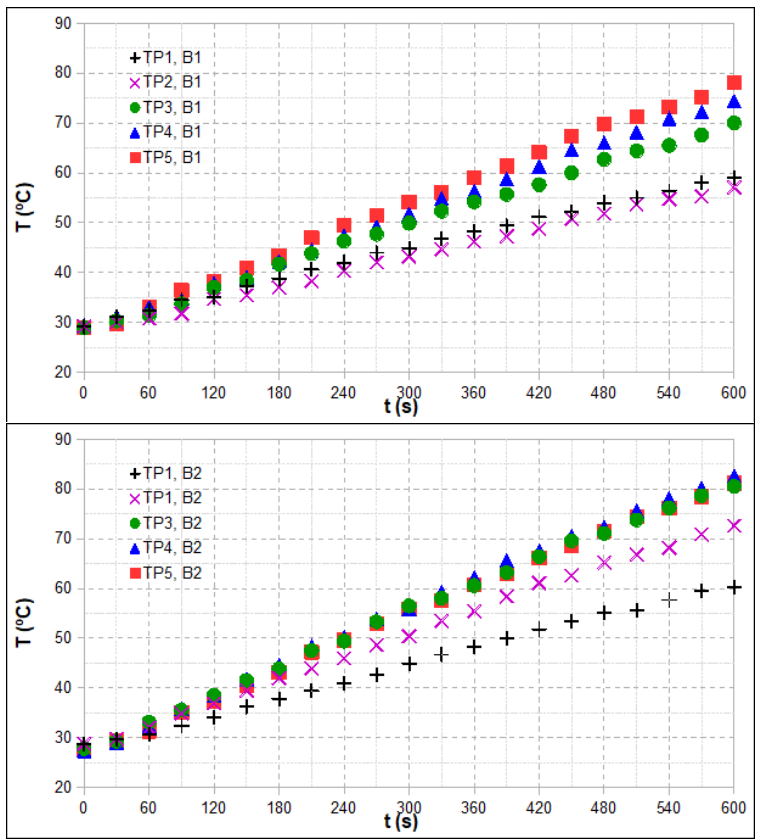

Figure 3. Heating capacity tests $-\Delta \mathrm{T}$ versus $\Delta \mathrm{t}$.
As a whole, higher temperatures occur for $\mathrm{AR}_{\mathrm{B} 2}$ (0.64); indicating that lower AR is preferable for the burner's geometry in this work. Similar behavior occurs for a slightly different geometry, radial holes as "circles/ellipses" instead of "rectangles" (Silva et al., 2017).

\section{Thermal power, $\boldsymbol{\eta}_{\text {Thermal }}$, and Reynolds behavior}

Results for $\mathrm{TP}_{\text {Nominal }}$ versus fuel mass flow $\left(\Delta \mathrm{m}_{\mathrm{g}} / \Delta \mathrm{t}\right)$ indicates a linear response, see Fig. 4 . It is following basic thermal theory, Eq. (1), once HHV remains constant (no changes in the fuel gas composition). Also, there is proper consistency when comparing theoretical and experimental data, also confirmed in a similar analysis for industrial burners fueled with LPG and NG (Rocha et al., 2010).

Maximum fuel consumption occurs at TP5 condition, being 25\% higher for B2 ( 3.20 kg.s $\left.{ }^{1} @ 1.58 \mathrm{E}-05 \mathrm{~kW}\right)$ in comparison to B1 ( 2.57 kg.s @@1.27E-05 kW); those differences reaches $~ 54 \%$ at TP2, comparing B2 ( 1.80 kg.s.-1@0.89E-05 kW) and B1 ( 1.17 kg.s $@ 0.58 \mathrm{E}-05 \quad \mathrm{~kW})$. Geometric differences in both burners are the main factor that implies in higher fuel mass consumption and TP: $\mathrm{De}_{\text {cap-2 }} / \mathrm{De}_{\text {cap-1 }} \sim 1.20$ and $\mathrm{AR}_{\mathrm{B} 2} / \mathrm{AR}_{\mathrm{B} 1} \sim 0.82$ (Tab. 1). As the volume inside the burner is lower for B2 $\left(\downarrow \mathrm{H}_{\text {cyl }}\right.$ and $\left.\downarrow D i_{\text {cyl }}\right)$, a higher amount of ambient air entrains inside B1, but in the other hand, B2 has larger distribution area for the flame front distribution $\left(\uparrow \mathrm{De}_{\mathrm{cap}}\right)$.

Thus, B2 seems to provide a better air-fuel ratio (once fuel mass flow is constant at each test condition) implying in higher temperature rise and $\mathrm{TP}$ values, and as a consequence, increasing fuel consumption.

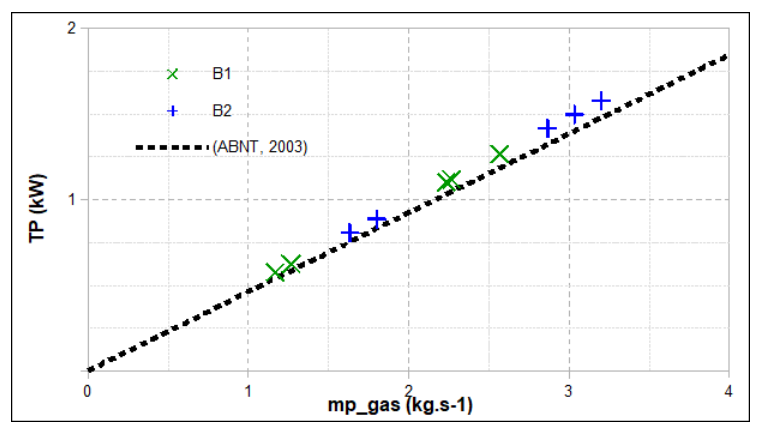

Figure 4. $\mathrm{TP}_{\text {Nominal }}$, experimental versus theoretical.

In Fig. 5, energy efficiency has a non-linear behavior as handle position selector moves forward. Both burners present the same response: $\eta_{\text {Thermal }}$ increases as TP position is moved forward, in the first two (B2) or three (B1) handle positions, then followed by a sudden drop (more prominent at B1); and, and after that $\eta_{\text {Thermal }}$ increases again reaching maximum values at TP5 (B2). Only at TP3 occurs $\eta_{\text {Thermal-B1 }}>\eta_{\text {Thermal-B2 }}$, while $\eta_{\text {Thermal-average }}$ is $\sim 22 \%$ and $\sim 32 \%$, for B1 and B2, respectively. In general, 
along with the operating range, B2 has better performance and reaches maximum $\eta_{\text {Thermal }}$ 45\%@1.58kW in this work; while nominal values indicated by the manufacturer is 62.2\%@1.67kW (Fig. 1c). In Thailand, the reference standard requirement for radial burners is $50 \%$ (Makmool et al., 2007). Once $\eta_{\text {Thermal }}$ is relatively low for open combustion flame devices, increases are possible (Jugjai and Rungsimuntuchart, 2002) by using a Porous Radiant Recirculated Burner (PRRB) and also Swirling central flame ring Burner (SB), for example.

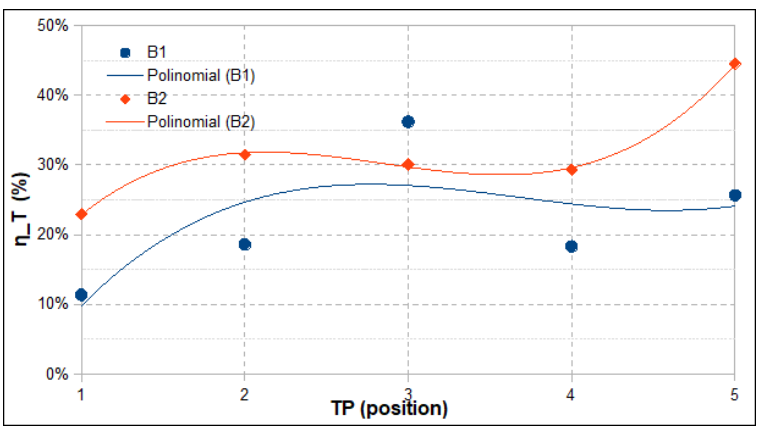

Figure 5. $\eta_{\text {Thermal }}$ as handle selector moves forward.

Uncertainty analysis for results in Figs. (4) and (5) is in Tab. 4. Fuel mass flow relative standard uncertainties are $<3 \%$ for $\mathrm{B} 1$ and $\leq 2 \%$ for $\mathrm{B} 2$. Regarding $\mathrm{TP}_{\text {experimental}}$, uncertainties are in the same order of magnitude $(\sim 1.6 \%)$ for both burners, indicating robust results.

Table 4. Experimental results uncertainties and Re.

\begin{tabular}{|c|c|c|c|c|}
\hline & & $\mathrm{mp}_{\text {gas }} \cdot 10^{-5}$ (kg.s & $\mathrm{TP}_{\text {Experimental }}(\mathrm{kW})$ & $\mathbf{R e}$ \\
\hline \multirow{2}{*}{ TP1 } & B1 & $1.267 \pm 2.6 \%$ & $0.625 \pm 1.6 \%$ & 165 \\
\hline & B2 & $1.633 \pm 2.0 \%$ & $0.806 \pm 1.6 \%$ & 222 \\
\hline \multirow{2}{*}{ TP2 } & B1 & $1.167 \pm 2.8 \%$ & $0.576 \pm 1.6 \%$ & 152 \\
\hline & B2 & $1.800 \pm 1.8 \%$ & $0.888 \pm 1.6 \%$ & 245 \\
\hline \multirow{2}{*}{ TP3 } & B1 & $2.267 \pm 1.5 \%$ & $1.118 \pm 1.6 \%$ & 296 \\
\hline & $\overline{\mathrm{B} 2}$ & $2.867 \pm 1.2 \%$ & $1.414 \pm 1.6 \%$ & 389 \\
\hline \multirow{2}{*}{ TP4 } & B1 & $2.233 \pm 1.5 \%$ & $1.102 \pm 1.6 \%$ & 291 \\
\hline & B2 & $3.033 \pm 1.1 \%$ & $1.496 \pm 1.6 \%$ & 412 \\
\hline \multirow{2}{*}{ TP5 } & B1 & $2.567 \pm 1.3 \%$ & $1.266 \pm 1.6 \%$ & 335 \\
\hline & B2 & $3.200 \pm 1.0 \%$ & $1.579 \pm 1.6 \%$ & 435 \\
\hline
\end{tabular}

As for Reynolds number (also in Tab. 4), all conditions indicate laminar flow ( $\operatorname{Re}<500)$. It is consistent with similar literature results which show $200<\operatorname{Re}<500$ when testing LPG $(70 \%$ butane and $30 \%$ propane, by volume) in a domestic burner with De $_{\text {cap }}=160 \mathrm{~mm}$ and premixed air/LPG flame jet ( $\mathrm{Li}$ et al., 2006). Furthermore, Re rises consistently as

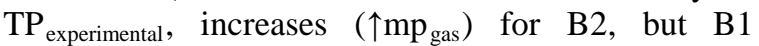
presents a slight drop from TP1 $\rightarrow$ TP2 (165 $\rightarrow$ 152) and TP3 $\rightarrow$ TP4 $(296 \rightarrow 291)$; probably a partial effect due to the behavior also available in Figs. 4 and 5, where forward movement on the handle position selector does not correspond to an increasing $\mathrm{TP}_{\text {Experimental }}$. Reynolds drops on B1 is probably due to some project oversight, once domestic gas burners manufacturers usually built those thermal equipment based on trial and error knowledge (Makmool et al., 2007). Also, literature reports that, for premixed airLPG composition, $\eta_{\text {Thermal }}$ decreases at an almost constant rate with an increasing Reynolds; once less space is available to enable complete burning for the air/LPG mixture (Kwok, Leung, and Cheung, 2003; Makmool et al., 2007).

\section{Flame temperatures and thermal images}

Qualitative temperature fields are in Fig. 6, once limit values are up to $650^{\circ} \mathrm{C}$ (E50 thermal camera). Quantitative results for flame temperatures (K-type thermocouple) indicates, from TP1 up to TP5, the following: a) $\mathrm{T}_{\text {flame-B1 }}\left({ }^{\circ} \mathrm{C}\right)$ equal to 697.9 ; 706.3; 733.3; 751.3; 741.5; b) $\mathrm{T}_{\text {flame-B2 }}\left({ }^{\circ} \mathrm{C}\right)=719.9 ; 750.7$; 818.4; 832.5; 830.7. Both qualitative and quantitative results have a close consistency to $\mathrm{Q}_{\mathrm{w}}$ and $\eta_{\text {Thermal }}$ results (Tab. 3 and Fig. 5). Flame temperature differences are $\geq 1200^{\circ} \mathrm{C}$ when comparing to theoretical values $\left(\mathrm{T}_{\text {adiabatic }} \sim 2028^{\circ} \mathrm{C}\right.$; Turns, 2013), indicating that a great amount of energy contained in the fuel $\left(\mathrm{HHV}_{\mathrm{LPG}}\right)$ is not being fully converted into heat energy $\left(\mathrm{Q}_{\text {gas }}\right)$. One possible reason is a nonstoichiometry fuel/air mixture, as occurs for excess air in the combustion process; probably to have $\mathrm{CO}$ emission as low as the values required by regulation in a domestic cooking appliance, typical when there is excess air ( $\mathrm{Li}$ et al., 2006).
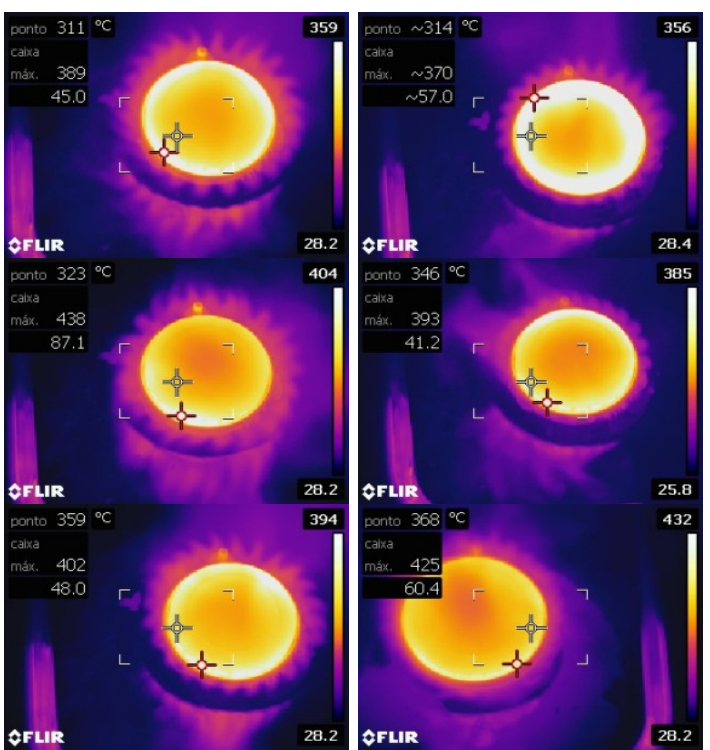

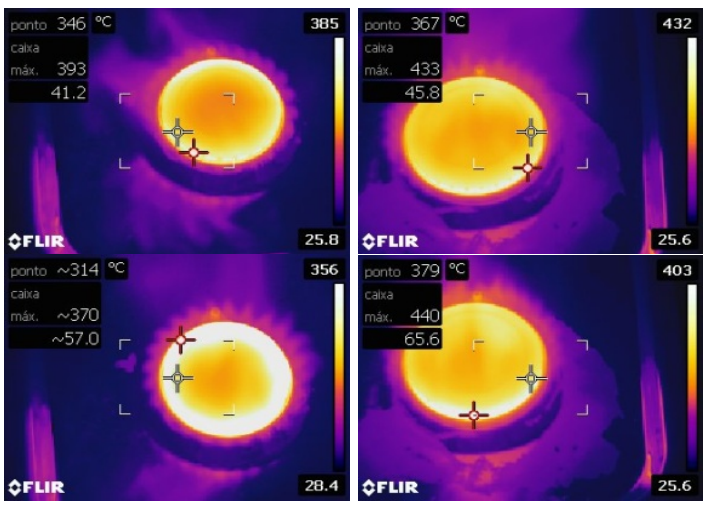

Figure 6. Temperature fields for B1 (left) and B2 (right), TP1 (top) to TP5 (bottom).

Radial burners yield relatively low CO emissions but usually with a significant difference in thermal efficiency, ranging from 34-63\% (Makmool et al., 2007), while in the present work $\eta_{\text {Thermal }} \sim 11$ $45 \%$ for the whole range of handle position selector. One possible reason to be pointed out is that the quenching effect of the flame in the water container's bottom is minimized by the flame jet being impinged obliquely and thus, reducing contact area for heat transfer in radial burners (Makmool and Jugjai, 2013). Improvements in $\eta_{\text {Thermal }}$ and enlarging operational range for premixed flames in domestic cookers was obtained in literature research when redesigning burners from conventional radial into swirl ones (Zhen et al., 2014).

In further research, redesign of radial burners into axial (vertical) ones is also a possibility to obtain and compare emissions from domestic gas burners; once it is well known in technical-scientific literature that manufacturers worldwide (like Brazil and Thailand, for example, see Makmool et al., 2007) built those burners on trial and error knowledge, lacking engineering $R \& D$. Fuel gas flow increase plays a significant role in $\mathrm{CO}$ and $\mathrm{NOx}$ concentrations, reducing the first one, and increasing the second one for $\mathrm{CH} 4$ and NG evaluation (Wagner et al., 2010). Another approach is to evaluate fuel blends for residential gas burners to obtain lower CO emissions; as investigated in recent works, it yields into decreases in $\eta_{\text {Thermal }}$ (Makmool and Jugjai, 2013).

\section{CONCLUSIONS}

In this work, cooker-top burners performance is investigated using Brazilian standards as a guideline, looking for support on energy efficiency labeling programs.

A recommendation that arises from experimental conclusions is that when operating domestic cookers with handle position selector on middle position (TP3) provides almost the same temperature rise $(\Delta T$ in the water container) as maximum fuel consumption (TP5). Heat is better transferred $\left(\mathrm{Q}_{\text {gas }} \rightarrow \mathrm{Q}_{\text {water }}\right)$ with the handle position selector fully opened (TP5 for B1) and just before fully opening (TP4 for B2).

A non-linear behavior is identified for $\eta_{\text {Thermal }}$, when moving forward the handles position selector, average values are $\sim 32 \%$ and $\sim 22 \%$ for B2 and B1, respectively. Nevertheless, maximum efficiency occurs at fully open (TP5@B2) and middle opening (TP3@B1).

Higher values for $\mathrm{TP}_{\text {experimental }}$ occurs for $\mathrm{B} 2$, in comparison to $\mathrm{B} 1$, in whole operational condition ranges (25 up to 54\%); differences are mainly due to geometric parameters, as $\mathrm{De}_{\text {cap-2 }} / \mathrm{De}_{\text {cap-1 }} \sim 1.20$ and $\mathrm{AR}_{\mathrm{B} 2} / \mathrm{AR}_{\mathrm{B} 1} \sim 0.82$. In general, $\mathrm{B} 2$ has a better geometric design and reaches maximum 45\%@1.58 $\mathrm{kW}$, while $1.67 \mathrm{~kW}$ is the nominal value indicated by the manufacturer.

Uncertainty analysis is lower than $\pm 3 \%$, proving to be a suitable methodology for the experimental results in this work.

Flame temperatures are entirely consistent with both, $\eta_{\text {Thermal }}$ and heat energy delivered, reaching higher temperature values at TP4 for both burners; $751.5^{\circ} \mathrm{C}(\mathrm{B} 1)$ and $830.7^{\circ} \mathrm{C}(\mathrm{B} 2)$.

\section{ACKNOWLEDGMENTS}

Support from UFGD/PROPP, grant 2012/0031 (2012-2015). To UFGD/FAEN Energy Engineering facilities where the experiments were carried out from ARENA/CNPq team assistance. To scholarships for engineering undergraduate students granted by CNPq, CAPES, and UFGD.

\section{REFERENCES}

ABNT - Associação Brasileira de Normas Técnicas, 2003, Aparelho Doméstico de Cocção a Gás - Parte 1: Desempenho e Segurança, NBR 13.723-1, 58p. (in Portuguese)

ABNT - Associação Brasileira de Normas Técnicas, 1999, Aparelho Doméstico de Cocção a Gás - Parte 2: Uso Racional de Energia, NBR 13.723-2, 3p. (in Portuguese)

ABNT - Associação Brasileira de Normas Técnicas, 2014, Ensaios não Destrutivos Termografia - Medição e Compensação da Temperatura Aparente Refletida Utilizando Câmeras Termográficas, NBR 16.292, 5p. (in Portuguese)

ABNT - Associação Brasileira de Normas Técnicas, 2016, Ensaios não Destrutivos Termografia - Medição e Compensação da Emissividade Utilizando Câmeras Termográficas ou Radiômetros, NBR 16.485, 4p. (in Portuguese)

ABNT - Associação Brasileira de Normas Técnicas, 2005, Regulador de Baixa Pressão para Gás Liquefeito de Petróleo (GLP) com Capacidade até 4 kg/h, NBR 8.473, 32p. (in Portuguese)

Balbinot, A., and Brusamarello, V. J., 2010, Instrumentação e Fundamentos de Medidas - Vol. 1, 


\section{LTC. 385p. (in Portuguese)}

Cassol, D., Muller, D., Bahia, F., and Petracco, T., 2007, Bancada para Análise da Eficiência da Queima de Gás em um Queimador Doméstico, Trabalho da Disciplina Medições Térmicas (ENG3108) - Engenharia Mecânica, Porto Alegre, UFRGS, 12p. (in Portuguese)

Hou, S. S., Lee, C. Y., and Lin, T. H., 2007, Efficiency and Emissions of a new Domestic Gas Burner with a Swirling Flame, Energy Conversion and Management, Vol. 48, No. 5, pp. 1401-1410.

INMETRO - Instituto Nacional de Metrologia, Qualidade e Tecnologia, 2012, Requisitos de Avaliação da Conformidade para Fogões e Fornos a Gás de Uso Doméstico, Portaria 400/2012, 3p. (in Portuguese)

Jugjai, S., and Rungsimuntuchart, N., 2002, High Efficiency Heat-Recirculating Domestic Gas Burners, Experimental Thermal and Fluid Science, Vol. 26, No. 5, pp. 581-592.

Ko, Y. C., and Lin, T. H., 2003, Emissions and Efficiency of a Domestic Gas Stove Burning Natural Gases with Various Compositions, Energy Conversion and Management, Vol. 44, No. 19, pp. 3001-3014.

Kwok, L. C., Leung, C, W., and Cheung, C. S., 2003, Heat-Transfer Characteristics of Slot and Round Premixed Impinging Flame Jets, Experimental Heat Transfer, Vol. 16, No. 2, pp. 111-137.

Li, H. B., Wong, T. T., Leung, C. W., and Probert, S. D., 2006, Thermal Performances and CO Emissions of Gas-Fired Cooked-Top Burners, Applied Energy, Vol. 83, No. 12, pp. 1326-1338.

Makmool, U., Jugjai, S., Tia, S., Vallikul, P., Fungtammasan, B., 2007, Performance and Analysis by Particle Image Velocimetry (PIV) of Cooker-Top Burners in Thailand, Energy, Vol. 32, No. 10, pp. 1986-1995.

Makmool, U., and Jugjai, S., 2013, Thermal Efficiency and Pollutant Emissions of Domestic Cooking Burners Using DME-LPG Blends as Fuel, in: 4th TSME International Conference on Mechanical Enginieering, Parraya, Chonburi.

Rocha, M. S., Neto, E. P., Panella, L. S., Ferreira, E. S., and Moreira, J. R. S., 2010, Conversion Methods for Commercial Stoves from LPG to Natural Gas Firing, in: 13th Brazilian Congress of Thermal Sciences and Engineering ENCIT 2010, Uberlândia, Brazil.

Turns, S. R., 2013, Introdução à Combustão: Conceitos e Aplicações, 3th Edition, AMGH. (in Portuguese)

Wagner, A. Y., Livbjerg, H., Kristensen, P. G., and Glarborg, P., 2010, Particle Emissions from Domestic Gas Cookers, Combustion Science and Technology, Vol. 182, No. 10, pp. 1511-1527.

Zhang, Y., Qin, C., Xing, H., and Liu, P., 2013, Experimental Research on Performance Response of Domestic Gas Cookers to Variable Natural Gas Constituents, Journal of Natural Gas Science and
Engineering, Vol. 10, No. 1, pp. 41-50.

Zhen, H. S., Leung, C. W., and Wong, T. T., 2014, Improvements of Domestic Cooking Flames by Utilizing Swirling Flows, Fuel, Vol. 119, No. 6, pp. 153-156. 